\title{
PERBANKAN DAN PERTUMBUHAN EKONOMI DI INDONESIA: ANALISIS ERROR CORRECTION MODEL
}

\author{
Yudhistira Ardana \\ IAIN Metro \\ Wulandari \\ STMIK Pringsewu \\ Dudi Septiadi \\ Universitas Mataram
}

\begin{abstract}
As an effort to encourage domestic economic growth, the role of banking is very important. This is related to the banking function, namely as a distributor and collector of public funds. This study aims to measure the effect of banking on economic growth in Indonesia. Banking variables in this study are proxied by Commercial Bank Assets, Commercial Bank Financing and the Number of Conventional Commercial Banks in Indonesia. Then the Economic Growth variable is proxied by Gross Domestic Product. The analysis in this study uses the Error Correction Model approach. The results showed that simultaneously both the short and long term banking variables had a positive and significant effect on economic growth in Indonesia. While the partial test results, both short
\end{abstract}

Paper type: Research paper

*Corresponding author: ardanayudhistira@gmail.com

Received: March 04, 2021; Accepted: November 13, 2021; Available online: December, 06, 2021

\section{Cite this document:}

Ardana, Y., Wulandari, \& Septiadi, D. (2021). Perbankan dan Pertumbuhan Ekonomi di Indonesia: Analisis Error Correction Model. Jurnal Masharif Al-Syariah: Jurnal Ekonomi dan Perbankan Syariah, 6(3), 691-708. doi:http://dx.doi.org/10.30651/jms.v6i3.7578

Copyright (C 2021, Jurnal Masharif Al-Syariah: Jurnal Ekonomi dan Perbankan Syariah http://journal.um-surabaya.ac.id/index.php/Mas/index

This article is licensed under a Creative Commons Attribution-NonCommercial 4.0 International License. 
and long term, the banking variable which is proxied by the number of commercial banks and conventional commercial bank financing has a negative and insignificant effect. Meanwhile, the variables of commercial bank assets, both short and long term, have a positive and significant effect.

Keywords: banking, economic growth

\section{Abstrak}

Sebagai upaya dalam mendorong pertumbuhan ekonomi dalam negeri, peran perbankan sangat penting dibutuhkan. Hal ini terkait dengan fungsi perbankan yaitu sebagai penyalur dan penghimpun dana masyarakat. Penelitian bertujuan untuk mengukur pengaruh perbankan terhadap pertumbuhan ekonomi di Indonesia. Variabel perbankan dalam penelitian ini diproksikan dengan Aset Bank Umum, Pembiayaan Bank Umum dan Jumlah Bank Umum konvensional yang ada di Indonesia. Kemudian variabel Pertumbuhan Ekonomi diproksikan dengan Produk Domestik Bruto. Analisis dalam penelitian ini menggunakan pendekatan Error Correction Model. Hasil penelitian menunjukkan bahwa secara simultan baik jangka pendek maupun jangka panjang variabel perbankan berpengaruh positif dan signifikan terhadap pertumbuhan ekonomi di Indonesia. Sementara hasil uji secara parsial, baik jangka pendek maupun jangka panjang, variabel perbankan yang diproksikan dengan Jumlah Bank Umum dan Pembiayaan Bank umum konvensional berpengaruh negatif tidak signifikan. Sedangkan variabel Aset Bank Umum baik jangka pendek maupun jangka panjang berpengaruh positif dan signifikan.

Kata Kunci: perbankan, pertumbuhan ekonomi

\section{PENDAHULUAN}

Perkembangan dan pertumbuhan keuangan telah dipelajari secara intensif di negara-negara maju menunjukkan hubungan positif yang kuat antara pertumbuhan dan perkembangan sektor keuangan (Ayadi et al, 2013). Perdebatan mengenai hubungan kausal antara perkembangan keuangan dan pertumbuhan ekonomi telah berlangsung sejak abad kesembilan belas. Inti dari perdebatan ini adalah apakah pertumbuhan sektor keuangan yang mendorong pertumbuhan sektor riil atau apakah pertumbuhan sektor riil yang memimpin perkembangan sektor keuangan (Odhiambo, 2008). Robinson 
(1952) berpendapat bahwa sektor keuangan tidak memberikan dampak kausal pada pertumbuhan ekonomi. Sebaliknya, perkembangan sektor keuanganlah yang mengikuti pertumbuhan ekonomi sebagai akibat dari permintaan yang lebih tinggi akan jasa keuangan. Namun ada beberapa studi empiris (misalnya, Al-Yousif, 2002; Demetriades dan Khaled, 1996) yang menunjukkan bahwa hubungan antara perkembangan keuangan dan pertumbuhan ekonomi tidak dapat digeneralisasikan antar negara karena kebijakan ekonomi berbeda dari satu negara ke negara lain dan oleh karena itu relevan untuk mempelajari satu negara pada satu waktu.

Pertumbuhan ekonomi dianggap sebagai tujuan penting oleh negaranegara di dunia. Namun demikian, proses pembangunan membutuhkan prasyarat untuk memenuhi keinginan manusia yang dapat terjadi melalui pembiayaan investasi dan produksi. Khususnya di negara berkembang yang mengalami banyak masalah ekonomi seperti pengangguran, kemiskinan, standar hidup yang rendah, dan inflasi. Oleh karena itu, negara-negara tersebut selalu berupaya menjaga pertumbuhan ekonominya untuk meningkatkan pendapatan nasionalnya dan menciptakan lebih banyak lapangan kerja guna meningkatkan taraf hidup mereka. Indonesia sebagai negara berkembang berusaha membangun bangsa tanpa mengharapkan bantuan dari negara lain. Namun sulit untuk bertahan di tengah deras arus globalisasi yang terus berkembang pesat. Dengan kondisi tersebut, Indonesia akhirnya harus mengikuti arus dengan menggandeng negara lain dalam pelaksanaan pembangunan nasional, khususnya ekonomi nasional bersama.

Sebagai negara berkembang, Indonesia dihadapkan pada keterbatasan akumulasi modal dalam negeri untuk membiayai pembangunan. Ketergantungan pada investasi asing, baik dalam bentuk portofolio investasi maupun pinjaman luar negeri, membuat Indonesia sangat rentan terhadap guncangan eksternal yang dapat mengganggu perekonomian. Bagi negara berkembang seperti Indonesia, arus modal yang deras merupakan peluang bagus untuk memperoleh pembiayaan pembangunan ekonomi. Namun, jika 
dananya diberikan melalui utang, maka lambat laun utang luar negeri seolah menjadi bumerang bagi Indonesia karena menyisakan banyak persoalan, terutama utang luar negeri yang memiliki suku bunga tinggi (Muqorrobin, 2015). Penyebab terbatasnya akumulasi modal domestik terutama di daerah adalah rendahnya aksesibilitas masyarakat Indonesia terhadap sektor keuangan (baik bank maupun lembaga keuangan lainnya). Keterbatasan infrastruktur dan kondisi alam pulau-pulau menjadi kendala bagi perbankan dalam memberikan pelayanan kepada masyarakat, terutama yang berada di daerah terpencil dan pedesaan. Keterbatasan layanan perbankan tersebut tidak lepas dari perhitungan skala ekonomi operasional bank di suatu wilayah dan pertimbangan bank mengenai sebaran penduduk di suatu wilayah yang akan dijangkau oleh layanan kantor cabang bank. Akibatnya, terdapat disparitas layanan perbankan untuk menjangkau seluruh wilayah administratif di tingkat provinsi, kabupaten, dan kecamatan.

Survei Literasi Keuangan Bank Indonesia 2012 menyimpulkan bahwa sebagian besar penduduk Indonesia memiliki kemampuan yang rendah untuk mengakses layanan keuangan bank. Hasil survei mencatat hanya $35,31 \%$ penduduk dewasa Indonesia yang terlayani oleh bank. Sementara itu, Survei Rumah Tangga Bank Indonesia tahun 2011 menunjukkan bahwa hanya 48\% rumah tangga Indonesia yang menabung di bank, lembaga keuangan non bank, dan lembaga non keuangan. Secara teoritis keterkaitan antara pertumbuhan dan tabungan adalah terjadinya mekanisme transmisi tabungan baik dalam bentuk riil maupun finansial menjadi akumulasi modal produktif, di samping peningkatan total produktifitas faktor. Perpindahan dana dari tabungan menjadi modal fisik dapat terjadi oleh aklifitas agen ekonomi, baik pemerintah, rumah tangga maupun industri. Pembangunan ekonomi di suatu negara sangat tergantung pada perkembangan dinamis dan kontribusi nyata dari sektor perbankan. Ketika sektor perbankan terpuruk perekonomian nasional juga ikut terpuruk (Zumaidah \& Soelistyo, 2018). Demikian pula 
sebaliknya, ketika perekonomian mengalami stagnasi sektor perbankan juga terkena imbasnya dimana fungsi intermediasi tidak berjalan normal.

Tabel 1. PDB dan Total Aset Bank Umum (dalam milyar)

\begin{tabular}{|l|r|r|r|r|}
\hline \multicolumn{1}{|c|}{ Tahun } & \multicolumn{1}{|c|}{2016} & 2017 & \multicolumn{1}{c|}{2018} & \multicolumn{1}{c|}{2019} \\
\hline PDB & $5,00 \%$ & $5,10 \%$ & $5,20 \%$ & $5,02 \%$ \\
\hline Aset Bank & $\mathrm{Rp}$ & $\mathrm{Rp}$ & $\mathrm{Rp}$ & $\mathrm{Rp}$ \\
Umum & 6.729 .799 & 7.387 .634 & 7.913 .491 & 8.220 .426 \\
\hline
\end{tabular}

Tabel 1 dapat dijelaskan bahwa tahun 2016 hingga 2018, PDB Indonesia mengalami kenaikkan tiap tahunnya. Hal tersebut juga diimbangin dengan nilai aset bank umum yang juga meningkat. Prosentase PDB Indonesia mulai dari tahun $2016-2018$ secara berturut-turut yaitu $5 \%, 5,1 \%$ dan 5,2\%. Sedangkan Nilai aset bank umum mulai dari 2016 - 2018 secara berturut-turut yaitu Rp 6.729.799 milyar, Rp 7.387.634 milyar dan Rp 7.913.491 milyar. Dapat disimpulkan bahwa mulai dari tahun 2016 - 2018 kenaikkan aset bank umum tiap tahunnya diikuti juga dengan peningkatan PDB Indonesia. tahun 2018 PDB Indonesia mengalami penurunan menjadi 5,02\% sedangkan aset bank umum tetap mengalami peningkatan dengan jumlah sebesar Rp 8.220.426 milyar. Terjadinya penurunan di tahun 2019 terkait dengan PDB Indonesia bisa terjadi karena pada kuartal terakhir tahun 2019, hampir seluruh dunia terkena dampak dari corona virus (covid-19) termasuk Indonesia. McKinnon (1973) berpendapat bahwa peningkatan layanan perbankan dan aktivitas keuangan mempercepat perekonomian menuju pertumbuhan. Hal tersebut didukung oleh King dan Levine (1993) yang berpendapat bahwa memberikan lebih banyak dana kepada perekonomian akan merangsang pergerakan roda ekonomi. Namun, Demetriades dan Hussein (1996) menguji kausalitas antara perkembangan keuangan dan pertumbuhan di 16 negara berkembang. Mereka menemukan bahwa tidak ada hubungan yang berarti antara perkembangan keuangan dan pertumbuhan ekonomi.

Calderon dan Liu (2003) menguji hubungan timbal balik antara perkembangan keuangan dan pertumbuhan ekonomi menggunakan data yang diperoleh dari 109 negara selama periode 1960 hingga 1994. Mereka 
menemukan bahwa dampak pertumbuhan ekonomi terhadap perkembangan keuangan menjadi signifikan dalam periode yang lama (negara-negara maju). Studi oleh Botric dan Slijepcevic (2008) menemukan bahwa efisiensi dalam sektor perbankan yang disebabkan oleh privatisasi dan masuknya bank asing di negara-negara Eropa Tenggara memiliki hubungan yang positif dengan pertumbuhan ekonomi negara-negara tersebut. Penelitian ini menggunakan suku bunga spread dan kredit bermasalah sebagai parameter efisiensi sektor perbankan, mereka menemukan penurunan suku bunga serta pinjaman buruk, secara positif mempengaruhi pertumbuhan ekonomi. Di Palestina, Alfara (2012) membahas tentang peran sektor perbankan dalam pembiayaan pembangunan ekonomi di Palestina selama periode 1995 hingga 2011. Hipotesisnya adalah bahwa pertumbuhan ekonomi dipengaruhi oleh beberapa indikator keuangan seperti: kredit perbankan, deposito, ukuran populasi , suku bunga hutang, dan jumlah cabang bank. Disimpulkan bahwa kredit perbankan berpengaruh positif terhadap produk domestik bruto, namun hubungan ini belum cukup untuk menjamin tercapainya pembangunan ekonomi di Palestina. Al-Khatib dan Al-Saffar (2013) meneliti keterkaitan antara pembangunan keuangan dan pertumbuhan ekonomi di Yordania antara periode 2001 dan 2012. Mereka menyimpulkan bahwa pembangunan sektor perbankan dan pertumbuhan ekonomi memiliki hubungan yang kuat terhadap permintaan. Artinya, perkembangan sektor perbankan sangat dipengaruhi oleh pertumbuhan ekonomi. Beberapa penelitian baru justru menunjukkan bahwa kredit perbankan dapat berdampak negatif terhadap pertumbuhan ekonomi. Arcand et al. (2012) dan Samargandi et al. (2015) menunjukkan bahwa sampai tingkatan tertentu, peningkatan kredit perbankan dapat mendorong pertumbuhan ekonomi.

Penelitian Medjahed dan Gherbi (2016) meneliti dampak perkembangan sektor perbankan terhadap pertumbuhan dengan menggunakan 11 negara MENA dari periode 1980 hingga 2012. Mereka menemukan bahwa perkembangan keuangan berdampak negatif pada hubungan jangka pendek 
dan jangka panjang dengan pertumbuhan ekonomi negara-negara MENA. Selain itu, Zhao (2017) menyelidiki dampak perkembangan keuangan terhadap output ekonomi menggunakan data dari 286 kota di Cina antara tahun 2007 - 2014. Hasil penelitian menggunakan model regresi cross sectional. Temuan tersebut mengungkapkan bahwa perkembangan keuangan tidak memiliki pengaruh positif yang signifikan terhadap pertumbuhan ekonomi Tiongkok. Namun beberapa variabel perbankan berpengaruh negatif terhadap pertumbuhan. Frikha dan McMillan (2016) meneliti peran bank syariah dalam pertumbuhan produk bruto domestik di 10 negara berkembang (Bahrain, Mesir, Yordania, Kuwait, Pakistan, Arab Saudi, Qatar, Sudan, Turki dan Uni Emirat Arab). Studi mereka menggunakan regresi kuadrat terkecil biasa untuk menguji 120 bank dari berbagai negara berkembang. Mereka menemukan bahwa bank konvensional mendukung pertumbuhan ekonomi.

Berdasarkan hasil penelitian yang sudah dijelaskan, masih ditemui adanya perbedaan antara peneliti yang satu dengan lainnya. Peneliti tertarik untuk mengembangkan lebih lanjut dengan judul Perbankan dan Pertumbuhan Ekonomi di Indonesia menggunakan Error Correction Model (ECM).

\section{METODE}

Dalam penelitian ini, data yang digunakan dibagi menjadi dua yaitu variabel dependen dan variabel independen. Variabel dependen yang digunakan yaitu Produk Domestik Bruto. Variabel independen yang digunakan yaitu Jumlah Bank Umum Konvensional, Aset Bank Umum Konvensional, dan Pembiayaan Bank Umum Konvensional. Metode dalam penelitian ini menggunakan metode kuantitatif. Bentuk data dalam penelitian yaitu time series, dimana data digunakan berupa data kuartalan mulai dari tahun 2011 hingga 2019. Dimana data-data tersebut bersumber dari Badan Pusat Statistik, Otoritas Jasa Keuangan dan Bank Indonesia. Penelitian ini menggunakan analisis regresi berganda menggunakan Error Correction Model (ECM). Error Correction Model (ECM) adalah regresi linier model yang menentukan keseimbangan jangka panjang antara beberapa variabel. Pada model koreksi 
kesalahan dilakukan penyesuaian agar ada keseimbangan antara apa yang diinginkan dan yang terjadi. Model koreksi kesalahan bisa digunakan pada variabel yang tidak stasioner tetapi terkointegrasi. Model koreksi kesalahan digunakan untuk mengatasi masalah data deret waktu non stasioner, masalah regresi, memperbaiki ketidakseimbangan jangka pendek dan untuk membentuk hubungan ekuilibrium jangka panjang antar variabel. Model persamaan Error Correction Model dalam penelitian ini yaitu sebagai berikut.

\section{Model Estimasi Jangka Panjang LnPDB $=\beta 0+\beta 1$ LnPBUt $+\beta 2$ LnABUt $+\beta 3$ LnJBUt + et}

\section{Model Estimasi Jangka Pendek $\Delta$ LnPDB $=\beta 0+\beta 1 \Delta$ LnPBUt-1 $+\beta 2 \Delta$ LnABUt-1 $+\beta 3 \Delta$ LnJBUt-1 + ECT}

Sebelum melakukan regresi menggunakan ECM, seluruh data harus di uji apakah terdapat data yang tidak stasioner pada tingkat level, jika data tidak stasioner pada tingkat level maka akan dilanjutkan dengan uji stasioneritas pada tingkat differensi. Jika hasilnya stasioner pada tingkat differensi selanjutnya adalah melakukan uji kointegrasi pada semua variabel dependen maupun independen. Jika semua variabel telah terkointegrasi selanjutnya adalah melakukan regresi dalam bentuk ECM dan akan mendapatkan nilai pada regresi ECM jangka pendek serta jangka panjang (Widarjono,2013).

\section{HASIL DAN PEMBAHSAN}

Untuk sampai ke tahap pengujian menggunakan Error Correction Model ada beberapa tahapan yang harus dilalui. Tahap pertama yaitu melakukan uji stasioneritas data. Uji stasioneritas bertujuan untuk mengetahui apakah data penelitian stasioner atau tidak. Jika data stasioner, maka data telah terhindar dari regresi lancung (meragukan). Regresi lancung ialah situasi dimana hasil regresi menunjukkan koefisien regresi yang signifikan secara statistik dan nilai koefisien determinasi yang tinggi tetapi hubungan antar variabel di dalam model tidak saling berhubungan (Widarjono, 2013). 
Tabel 2. Uji Akar Unit

\begin{tabular}{|c|c|c|c|c|}
\hline \multirow[t]{2}{*}{ Variabel } & \multicolumn{2}{|c|}{ Nilai ADF } & \multicolumn{2}{|c|}{$\begin{array}{c}\text { Nilai Kritis MacKinnon } \\
5 \%\end{array}$} \\
\hline & Level & $\begin{array}{c}\text { 1st } \\
\text { Difference }\end{array}$ & Level & $\begin{array}{c}1 \text { st } \\
\text { Difference }\end{array}$ \\
\hline PDB & $\begin{array}{c}- \\
1.627112\end{array}$ & -5.169086 & $\begin{array}{c}- \\
2.981038\end{array}$ & -2.976263 \\
\hline $\begin{array}{l}\text { Pembiayaan Bank } \\
\text { Umum }\end{array}$ & -4.273634 & - & $\begin{array}{c}- \\
2.948404\end{array}$ & - \\
\hline Aset Bank Umum & $\begin{array}{c}- \\
3.110426\end{array}$ & - & $\begin{array}{c}- \\
2.948404\end{array}$ & - \\
\hline Jumlah Bank Umum & -0.295701 & -7.803601 & $\begin{array}{c}- \\
2.948404\end{array}$ & -2.951125 \\
\hline
\end{tabular}

Berdasarkan tabel 2 dapat dijelaskan bahwa terdapat dua variabel yang sudah stasioner pada tingkat level dan dua variabel lainnya stasioner pada first difference. Variabel PDB tidak stasioner pada level hal ini bisa dilihat dari hasil pengujian pada tingkat level dimana nilai ADF kurang dari nilai kritis Mackinnon $5 \%(-1.627112<-2.981038)$. Variabel yang tidak stasioner selanjutnya yaitu Jumlah Bank Umum nilai ADF kurang dari nilai kritis Mackinnon 5\% (-0.295701 $<-2.948404)$. Sedangkan variabel Pembiayaan Bank Umum dan Aset Bank Umum sudah stationer pada tingkat level dimana nilai ADF sudah lebih dari nilai kritis Mackinnon 5\% secara berturut-turut yaitu -4.273634 > -2.948404 dan $-3.110426>-2.948404$. Untuk dapat melanjutkan ke tahap uji selanjutnya dalam Error Correction Model, seluruh data harus bersifat stasioner. Setelah diuji kembali, pada first difference variabel PDB dan Jumlah Bank Umum sudah stasioner dimana secara berturut-turut hasil uji first difference yaitu -5.169086 $>-2.976263$ dan -7.803601 > -2.951125. Berdasarkan uji augmented dickeyfuller (ADF) semua variabel telah stasioner pada nilai kritis Mackinnon 5\%. Sehingga dapat disimpulkan bahwa semua variabel telah stasioner pada first difference dan siap digunakan dalam analisis Error Correction Model. Sehingga sudah dapat dilanjutkan untuk uji selanjutnya yaitu uji derajat kointegrasi. 
Uji kointegrasi dilakukan untuk mengetahui hubungan jangka panjang antar variabel. Jika variabel menunjukkan adanya kointegrasi maka terdapat hubungan jangka panjang. Sebaliknya jika variabel tidak menunjukkan adanya kointegrasi maka tidak terjadi hubungan jangka panjang. Kointegrasi antar variabel dapat dilihat dengan membandingkan antara nilai trace statistic dengan nilai kritisnya. Apabila nilai trace statistic > nilai kritisnya (pada $\alpha=1 \%$, $5 \%, 10 \%)$ maka terdapat kointegrasi antar variabel. Sebaliknya apabila trace statistic < nilai kritisnya (pada $\alpha=1 \%, 5 \%, 10 \%$ ) maka tidak terdapat kointegrasi antar variabel. Hasil uji kointegrasi pada penelitian ini disajikan pada tabel 3.

Tabel 3. Uji Kointegrasi

\begin{tabular}{|c|c|c|c|c|}
\hline $\begin{array}{l}\text { Hypothesize } \\
d \\
\text { No. of } C E(s)\end{array}$ & Eigenvalue & $\begin{array}{c}\text { Trace } \\
\text { Statistic }\end{array}$ & $\begin{array}{c}0.05 \\
\text { Critical Value }\end{array}$ & Prob. ${ }^{* *}$ \\
\hline None * & 0.643144 & 67.05514 & 47.85613 & 0.0003 \\
\hline At most 1 * & 0.411197 & 32.02074 & 29.79707 & 0.0273 \\
\hline At most 2 & 0.283231 & 14.01219 & 15.49471 & 0.0826 \\
\hline At most 3 & 0.076072 & 2.690113 & 3.841466 & 0.1010 \\
\hline
\end{tabular}

Tabel 3 dapat dijelaskan bahwa terdapat minimal satu nilai trace statistic $>$ nilai kritisnya pada derajat $5 \%$ yaitu $32.02074>29.79707$. Hal ini menunjukkan bahwa data tersebut mempunyai hubungan jangka panjang. Model selanjutnya adalah pengujian regresi jangka panjang dan regresi jangka pendek. 
Tabel 4. Estimasi ECM Jangka Panjang

\begin{tabular}{crrrr}
\hline \hline & \multicolumn{2}{c}{ Coefficien } & & \\
Variable & $\mathrm{t}$ & Std. Error & $\mathrm{t}$-Statistic & Prob. \\
\hline \hline $\mathrm{C}$ & 11.79454 & 3.636807 & 3.243103 & 0.0028 \\
$\mathrm{JBU}$ & -1.568714 & 0.625756 & -2.506909 & 0.0175 \\
$\mathrm{PBU}$ & -0.599364 & 0.269428 & -2.224578 & 0.0333 \\
$\mathrm{ABU}$ & 1.276389 & 0.302837 & 4.214767 & 0.0002 \\
\hline \hline & & & & 1083.12 \\
R-squared & 0.990248 & F-statistic & 2 \\
Adjusted R- & & & 0.00000 \\
squared & 0.989334 & Prob(F-statistic) & 0 \\
\hline \hline
\end{tabular}

Berdasarkan tabel 4 dapat dijelaskan bahwa nilai probabilitas (F-Statistic) sebesar 0.000000 dimana nilai probabilitas $0.000000<0.05(\alpha=5 \%)$ maka dapat disimpulkan bahwa seluruh variabel independen yang digunakan dalam penelitian ini (Jumlah Bank Umum, Pembiayaan Bank Umum dan Aset Bank Umum) secara bersama-sama berpengaruh secara signifikan terhadap variabel dependen Perekonomian Indonesia (PDB). Selain itu dapat juga dijelaskan bahwa nilai koefisien determinasi (Adjusted $R$ Square) dari estimasi Error Correction Model sebesar 0.989334, yang berarti bahwa kemampuan variabel independen dalam jangka panjang mampu menjelaskan perubahan nilai pada variabel dependen adalah sebesar $98.83 \%$ dan sisanya sebesar $1.17 \%$ dipengaruhi oleh faktor-faktor lain di luar model.

Untuk menyatakan apakah Error Correction Model yang digunakan sahih atau tidak, maka koefisien Error Corection Term (ECT) harus signifikan. Jika hasil menunjukkan tidak signifikan maka model tersebut tidak cocok dan perlu dilakukan perubahan spesifikasi lebih lanjut. Nilai ECT digunakan untuk mencari perbedaan koefisien jangka pendek dan jangka panjang. Oleh karena itu nilai ini sering disebut disequilibrium error. 
Tabel 5. Uji ECT

\begin{tabular}{lccc}
\hline \hline & t-Statistic & Prob. $^{*}$ \\
\hline \hline \multicolumn{2}{l}{ Augmented Dickey-Fuller test statistic } & -3.468169 & 0.0168 \\
\hline Test critical & 1\% level & -3.689194 & \\
values: & $5 \%$ level & -2.971853 & \\
& 10\% level & -2.625121 & \\
\hline \hline
\end{tabular}

Nilai Error Correction Term pada tabel 5 sudah stasioner pada level dan dapat dikatakan terjadi integrasi. Untuk melihat model jangka pendek, dapat meregresikan semua variabel pada difference dengan data error lag 1 (et-1). Pada tabel 5, nilai probabilitas Error Correction Term (ECT) sebesar 0.0168 yang berarti signifikan karena nilainya kurang dari $5 \%$. Artinya Error Correction Model yang digunakan dalam penelitian ini sudah tepat dan dapat disimpulkan bahwa keseluruhan variabel independen dalam penelitian ini dapat berpengaruh terhadap variabel dependen, selain itu memberikan efek jangka panjang dan jangka pendek terhadap variabel dependen.

Tabel 6. Estimasi ECM Jangka Pendek

\begin{tabular}{crrrr}
\hline \hline & \multicolumn{2}{c}{ Coefficien } & & \\
Variable & $\mathrm{t}$ & Std. Error & $\mathrm{t}$-Statistic & Prob. \\
\hline \hline C & 11.79454 & 3.636807 & 3.243103 & 0.0028 \\
JBU & -0.295495 & 0.266570 & -1.108507 & 0.2762 \\
PBU & -0.163653 & 0.418018 & -0.391498 & 0.6981 \\
ABU & 0.831490 & 0.462518 & 1.797746 & 0.0820 \\
ECT(-1) & -0.058288 & 0.013103 & -4.448587 & 0.0001 \\
\hline \hline & & & & 3.09720 \\
R-squared & 0.255612 & F-statistic & 7 \\
Adjusted R- & & & 0.03014 \\
squared & 0.183574 & Prob(F-statistic) & 1 \\
\hline \hline
\end{tabular}

Pada tabel 6 dapat dijelaskan bahwa, hasil estimasi Error Correction Model pada jangka pendek secara keseluruhan variabel yang digunakan dalam penelitian ini yaitu Jumlah Bank Umum, Pembiayaan Bank Umum dan 
Aset Bank Umum secara simultan berpengaruh terhadap Perekonomian di Indonesia (PDB). Hal tersebut dibuktikan dengan nilai probabilitas F-statistic kurang dari taraf signifikansi $5 \%(0.0030141<0.05)$. Kemudian jika dianalisis lebih lanjut secara parsial pada taraf signifikansi $5 \%$, tidak terdapat pengaruh yang signifikan antara Jumlah Bank Umum, Pembiayaan Bank Umum dan Aset Bank Umum terhadap Perekonomian Indonesia (PDB). Namun ada satu variabel yang secara parsial berpengaruh secara signifikan terhadap Perekonomian Indonesia (PDB) pada taraf signifikansi 1\% yaitu Aset Bank Umum. Hal tersebut dibuktikan dengan nilai probabilitas Aset Bank Umum yang kurang dari $1 \%(0.00820<0.1)$.

Estimasi jangka pendek Jumlah Bank Umum Konvensional ditemukan nilai koefisiennya sebesar -0.295495 serta memiliki t-statistik sebesar 1.108507 dengan probabilitas 0.2762 . Besaran koefisien pada jangka pendek berarti bahwa setiap peningkatan Jumlah Bank Umum Konvensional sebesar 1\% maka akan diikuti dengan penurunan rasio PDB sebesar 0.295495 milyar. Dari hasil yang ditemukan tersebut jumlah bank konvensional berpengaruh negatif terhadap pertumbuhan ekonomi di Indonesia. Dalam jangka panjang didapatkan koefisien jumlah bank konvensional sebesar -1.568714 serta tstatistik sebesar -2.506909 dengan probabilitas sebesar 0.0175. Besaran koefisien pada jangka panjang ini menunjukkan bahwa setiap adanya peningkatan Jumlah Bank Umum Konvensional sebesar 1\% maka akan diikuti dengan penurunan rasio PDB sebesar 1.568714 milyar. Maka dapat dikatakan jumlah bank konvensional berpengaruh negatif terhadap pertumbuhan ekonomi. Hasil penelitian tersebut didukung oleh Medjahed dan Gherbi (2016) yang menemukan bahwa perkembangan keuangan berdampak negatif pada hubungan jangka pendek dan jangka panjang dengan pertumbuhan ekonomi negara-negara MENA. Selain itu, Zhao (2017) menyelidiki dampak perkembangan keuangan terhadap output ekonomi menggunakan data dari 286 kota di Cina antara tahun 2007 - 2014. Hasil penelitian menggunakan model regresi cross sectional. Temuan tersebut mengungkapkan bahwa 
perkembangan keuangan tidak memiliki pengaruh positif yang signifikan terhadap pertumbuhan ekonomi Tiongkok. Selain itu penelitian Arcand et al. (2012) dan Samargandi et al. (2015) menunjukkan bahwa sampai tingkatan tertentu, peningkatan kredit perbankan dapat mendorong pertumbuhan ekonomi. Apabila secara agregat alokasi kredit terlampau besar, maka peningkatan kredit dapat menurunkan pertumbuhan ekonomi karena terdapat productivity shift effects dari sektor riil ke sektor finansial. Dengan demikian, dimungkinkan bahwa hubungan antara perkembangan sektor finansial dan pertumbuhan ekonomi bersifat non-linear, atau kurva-U terbalik. Dengan bertambahnya jumlah berbankan tidak serta merta dapat meningkatkan PDB negara Indonesia.

Variabel Pembiayaan Bank Umum Konvensional dalam jangka pendek ditemukan nilai koefisiennya sebesar -0.163653 serta memiliki t-statistik sebesar -0.391498 dengan probabilitas 0.6981 . Besaran koefisien pada jangka pendek berarti bahwa setiap peningkatan Pembiayaan Bank Umum Konvensional sebesar $1 \%$ maka akan diikuti dengan penurunan rasio PDB sebesar 0.391298 milyar. Dari hasil yang ditemukan tersebut pembiayaan bank konvensional berpengaruh negatif terhadap pertumbuhan ekonomi di Indonesia. Dalam jangka panjang didapatkan koefisien pembiayaan bank konvensional sebesar -0.599364 serta t-statistik sebesar -2.224578 dengan probabilitas sebesar 0.0333 . Besaran koefisien pada jangka panjang ini menunjukkan bahwa setiap adanya peningkatan Pembiayaan Bank Umum Konvensional sebesar 1\% maka akan diikuti dengan penurunan rasio PDB sebesar 2.224578 milyar. Dapat disimpulkan bahwa pembiyaan bank umum konvensional baik jangka pendek maupun jangka panjang berpengaruh negatif tidak signifikan. Hasil negatif ini bisa dijelaskan karena semakin tinggi biaya yang dikeluarkan oleh perbankan nasional, maka pendapatan nasional bisa semakin berkurang akibat adanya gagal bayar dari para debitur. Hal ini bisa saja terjadi jika para pengusaha yang melakukan pinjaman di bank, tidak dapat melunasi hutangnya dikarenakan perusahaan tidak mendapatkan keuntungan 
seperti yang diharapkan bahkan cenderung mengalami kerugian. Kondisi ekonomi global juga turut andil dalam kesehatan ekonomi di Indonesia. Jika terjadi goncangan ekonomi global maka akan berdampak pada perputaran ekonomi di Indonesia, sehingga dapat menyebakan perusahaan mengalami kerugian akibat tidak adanya daya beli masyarakat yang kuat. Walaupun secara teori pembiayaan bank konvensional dapat meningkatkan PDB, tetapi dalam kondisi tertentu justeru akan terjadi sebaliknya karena terjadinya kondisi ekonomi yang tidak biasa. Hasil penelitian ini sesuai dengan hasil penelitian Zhao (2017) temuan tersebut mengungkapkan bahwa perkembangan keuangan tidak memiliki pengaruh positif yang signifikan terhadap pertumbuhan ekonomi Tiongkok.

Variabel Aset Bank Umum Konvensional dalam jangka pendek ditemukan nilai koefisiennya sebesar 0.831490 serta memiliki t-statistik sebesar 1.797746 dengan probabilitas 0.0820 . Besaran koefisien pada jangka pendek berarti bahwa setiap peningkatan Aset Bank Umum Konvensional sebesar 1\% maka akan diikuti dengan kenaikkan rasio PDB sebesar 1.797746 milyar. Dari hasil yang ditemukan tersebut aset bank konvensional berpengaruh positif terhadap pertumbuhan ekonomi di Indonesia. Dalam jangka panjang didapatkan koefisien aset bank konvensional sebesar 1.276389 serta t-statistik sebesar 4.214767 dengan probabilitas sebesar 0.0002 . Besaran koefisien pada jangka panjang ini menunjukkan bahwa setiap adanya peningkatan Aset Bank Umum Konvensional sebesar 1\% maka akan diikuti dengan kenaikkan rasio PDB sebesar 4.214767 milyar. Dapat disimpulkan bahwa aset bank umum konvensional pada jangka pendek berpengaruh positif signifikan pada tingkat signifikansi 10\% dan jangka panjang perpengaruh positif signifian pada tingkat signifikansi $5 \%$. Hasil penelitian ini sesuai dengan Al-Khatib dan Al-Saffar (2013) yang meneliti keterkaitan antara pembangunan keuangan dan pertumbuhan ekonomi di Yordania antara periode 2001 dan 2012. Mereka menyimpulkan bahwa pembangunan sektor perbankan dan pertumbuhan ekonomi memiliki 
hubungan yang kuat terhadap permintaan. Artinya, perkembangan sektor perbankan sangat dipengaruhi oleh pertumbuhan ekonomi. Secara teori semakin besar jumlah aset perbankan, maka kemampuan bank untuk memutarkan modalnya juga akan besar. Tentunya hal tersebut berdampak positif pada pertumbuhan ekonomi. Sebab banyak sektor yang membutuhkan modal tambahan sebagai upaya untuk mengembangkan usahanya. Dengan harapan, adanya perputaran modal yang cepat, kondisi perekonomian yang stabil dan juga ditambah oleh daya beli masyarakat yang kompotitif maka hal tersebut akan dapat berdampak positif pada pertumbuhan ekonomi di Indonesia.

\section{KESIMPULAN}

Produk Domestik Bruto sangat dipengaruhi oleh beberapa indikator perbankan diantaranya yaitu jumlah bank, pembiayaan dan total aset yang dimiliki perbankan. Hasil penelitian menemukan bahwa variabel jumlah bank umum dan pembiayaan bank umum baik jangka pendek maupun jangka panjang berpengaruh negatif dan tidak signifikan terhadap pertumbuhan ekonomi (PDB) di Indonesia. Selanjutnya variabel aset bank umum di Indonesia baik jangka pendek maupun jangka panjang berpengaruh positif dan signifikan terhadap pertumbuhan ekonomi (PDB) di Indonesia. Penelitian ini memberikan rekomendasi bahwa bank-bank di Indonesia harus menurunkan biaya utang untuk menyediakan lebih banyak pendanaan domestik dan untuk meningkatkan kebijakan kredit mereka dalam tujuan memperkuat kapasitas dan investasi dalam melakukan penggalangan dana lokal sehingga pertumbuhan ekonomi di Indonesia tetap terjaga tingkat kestabilannya. Hasil penelitian ini sebaiknya diinterpretasikan dengan berbagai pertimbangan mengingat jumlah sampel yang digunakan terbatas. Saran penulis, penelitian selanjutnya sebaiknya dapat dilakukan dengan menggunakan variabelvariabel proksi yang lebih luas dan beragam. 


\section{DAFTAR PUSTAKA}

Alfara, M., 2012, the role of the banking sector in financing the Palestinian Economic Development (1995 - 2011). Master thesis. Islamic University. Gaza. Palestine.

Al-khatib H., and Al-saffar, H., 2013, Financial Development and Economic Growth in Jordan (2001-2012). Interdisciplinary Journal of Contemporary Research in Business. 6(6), 176- 189.

Al-Yousif, Y.K. (2002), Financial development and economic growth: Another look at the evidence from developing countries. Review of Financial Economics, 11(2), 131-150.

Arcand, J., Berkes, E., \& Panizza, U. (2012) "Too much finance?" IMF Research Department.

Ayadi, R., Arbak, E., Ben-Naceur, S., \& De Groen, M. P. 2013. Financial Development, Bank Efficiency and Economic Growth across the Mediterranean. MEDPRO Technical Report No. 30/March 2013.

Botric, V., Slijepcevic, S. (2008), Economic growth in South-Eastern Europe: The role of the banking sector. Post-Communist Economies, 20(2), 253262.

Calderon, C., \& Liu, L., 2003, the direction of causality between financial development and economic growth. Journal of development Economics 72, 321-334.

Demetriades, P.O., Khaled, A.H. (1996), Does financial development cause economic growth? Time-series evidence from 16 countries. Journal of Development Economics, 51(2), 387-411.

Frikha, M and McMillan D. 2016, Banks and economic growth in developing countries: What about Islamic banks?. Journal Cogent Economic and Finance. 4(1).

King, R., \& Levine, R., 1993, Finance and growth. Schumpeter might be right. Policy research. (Working papers, 1083).

McKinnon, R. I., 1973, Money and Capital in Economic Development Washington, D.C. Brookings Institution.

Medjahed K. and Gherbi S., 2016, The Effect of the Financial Sector development on Growth: The case of the MENA countries. Arab Economic and Business Journal. Issue 2, 72-85.

Muqorrobin, Y. 2015. Factors Influencing Economic Growth In Indonesia: Error Correction Model (ECM). Jurnal Ekonomi dan Studi Pembangunan, (16)1, 1-13.

Odhiambo, N.M. (2008), "Financial Depth, Savings and Economic Growth in Kenya: A Dynamic Causal Linkage," Economic Modelling, 25 (4), 704713.

Robinson, J. 1952. The Generalization of the General Theory in: The Rate of Interest and other Essays. McMillian, London. 
Samargandi, N., Fidrmuc, J. and Ghosh, S. (2015) "Is the relationship between financial development and economic growth monotonic? Evidence from a sample of middle income countries" World Development, 68, 66-81.

Widarjono, A. (2013). Ekonometrika Teori dan Aplikasi. Yogyakarta: UPP STIM YKPN.

Zhao, S., 2017, Does Financial Development Necessarily Lead to Economic Growth? Evidence from China's Cities, 2007-2014. 13th Global Congress on Manufacturing and Management.

Zumaidah, L. N. \& Soelistyo, A. 2018. Pengaruh Total Aset, Dana Pihak Ketiga, Dan Kredit Pada Bank Umum Terhadap Pertumbuhan Ekonomi ProvinsiProvinsi Di Indonesia Pada Tahun 2013-2016. Jurnal IImu Ekonomi, 2(2), $251-263$ 